J. Perinat. Med. 15 (1987) 105

\title{
The fetus with an abdominal wall defect: management and outcome
}

\author{
Alessandro Calisti, Carlo Manzoni, and Luigi Perrelli
}

Division of Pediatric Surgery, Catholic University of "Sacro Cuore", Rome, Italy

\section{Introduction}

The prenatal diagnosis of an abdominal wall defect has frequently been reported. With ultrasonography, omphalocele and gastroschis may be discovered at an early gestational age, allowing prenatal transport of the affected fetus to a center which is specialized in high risk obstetric and pediatric surgical care. The ultrasonographic characteristics of omphalocele (figure 1) include the presence of abdominal viscera in a sac at the base of the umbilical cord. This picture may be distinguished from that typical of gastroschisis, where free loops of bowel or solid organs appear floating in the amniotic sac (figure 2). A five years experience on treatment of prenatally diagnosed abdominal wall defects is here reported.

\section{Material and methods}

Fourteen cases with fetal abdominal wall defect (12 omphalocele and 2 gastroschisis) were collected by routine maternal ultrasonography between the 16th and the 36th week of pregnancy in the Obstetrical Department of the Catholic University of Rome between January 1980 and April 1985. Antepartum planning for treatment following delivery was made in collaboration with the Pediatric Surgical Section of the same institution. Prenatal findings, obstetrical histories, clinical presentation and outcome are described in table I.

\section{Curriculum vitae}

Alessandro Calisti was born in Rome, Italy in 1946. He received his medical degree at the Catholic University of Rome in 1971. His postgraduate training was in Italy, and at the Hospital for Sick Children, London. He is a specialist in Pediatric Surgery and Urology. He is currently teaching and

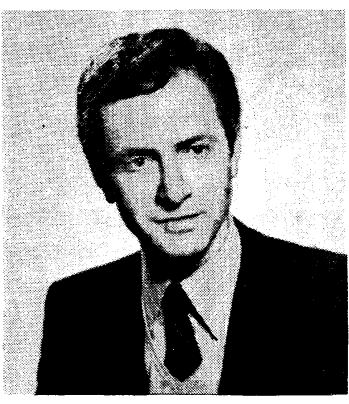
working at the Catholic University of Rome, Division of Pediatric Surgery. His main fields of interest are neonatal surgery and prenatal diagnosis and the surgical treatment of congenital malformations.

During the same period, 16 additional cases of abdominal wall defects (11 omphalocele and 5 gastroschisis) which had not been detected in utero (inborn or outside referrals) were observed and treated. A comparison was made between those antenatally detected (group B 2) and those which were not antenatally detected (group B 1) in order to evaluate the influence of prenatal diagnosis on survival (tables II-III). The mode of treatment, associated anomalies and incidence of immaturity/low birth weight were recorded. Causes of death were analyzed. 


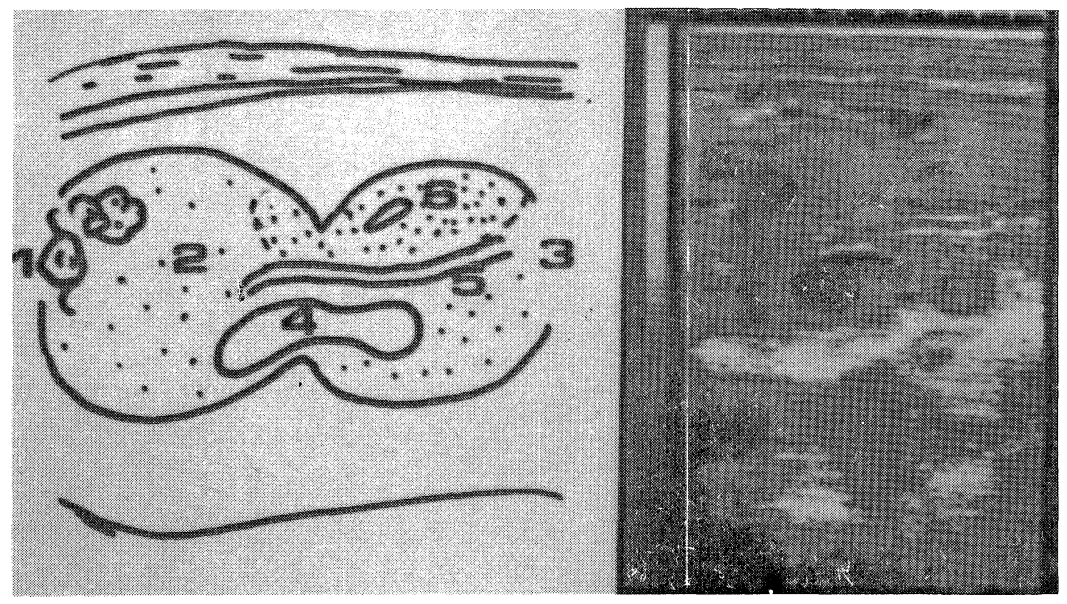

Figure 1. Transverse scan of a male fetus with omphalocele at 32 weeks. $1=$ Spine; $2=$ Fetal abdomen; $3=$ Omphalocele; 4 = Stomach; $5=$ Umbilical vessels; $6=$ Liver.
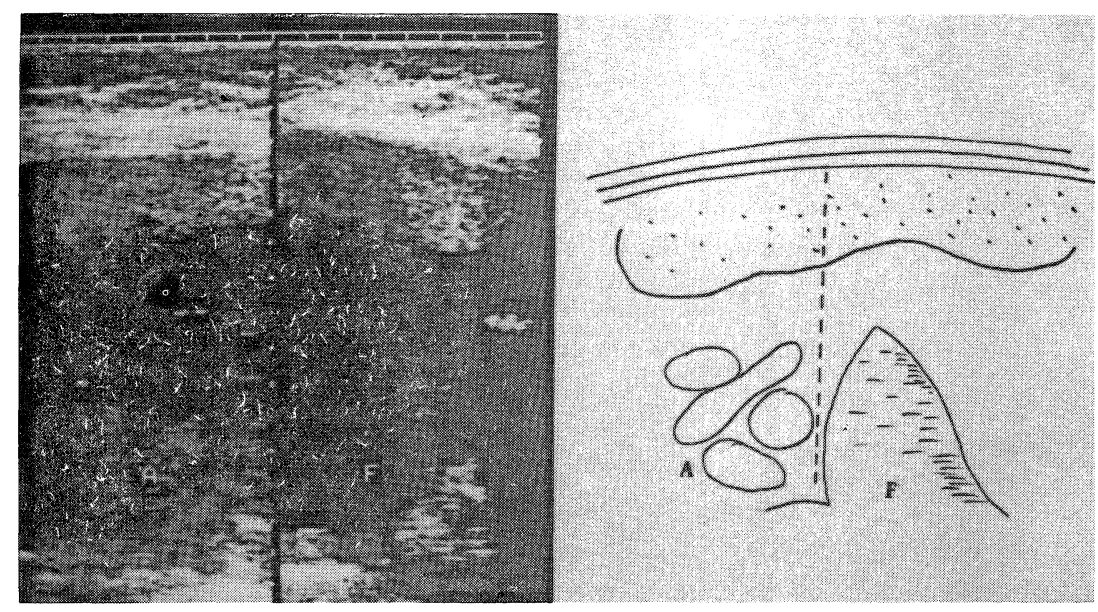

Figure 2. Longitudinal scan of a female fetus at 29 weeks. $\mathrm{F}=$ Liver; $\mathrm{A}=$ Intestinal loops floating in the amniotic fluid.

The same type of review was carried out in 55 cases of abdominal wall defects (tables II-III, group A) which were inborn or referred from elsewhere and treated in our institution but were from the October 1967 to December 1979 interval. There were no prenatally diagnosed cases included in this group.

\section{Results}

For omphalocele the incidence of associated anomalies and immaturity/low birth weight rate was very similar in groups A and B 1. Combined abnormalities were severe in most of the cases, and more than one third affected the 
Table I. Abdominal wall defects detected in utero (jan. 1980 - apr. 1985).

\begin{tabular}{|c|c|c|c|c|c|c|c|c|}
\hline $\begin{array}{l}\text { Case } \\
\text { no. }\end{array}$ & Sex & $\begin{array}{l}\text { Time of } \\
\text { diag- } \\
\text { nosis }\end{array}$ & $\begin{array}{l}\text { Mater- } \\
\text { nal } \\
\text { age }\end{array}$ & $\begin{array}{l}\text { Maturity } \\
\text { B.W. }\end{array}$ & $\begin{array}{l}\text { Deliv- } \\
\text { ery }\end{array}$ & $\begin{array}{l}\text { Size } \\
\text { of the } \\
\text { defect }\end{array}$ & $\begin{array}{l}\text { Associated } \\
\text { anomalies }\end{array}$ & Outcome \\
\hline I & M & $36 \mathrm{~W}$ & 36 yrs & $39 \mathrm{~W} / 2850 \mathrm{~g}$. & C.S. & $>5 \mathrm{cms}$ & Club feet & $\begin{array}{l}\text { Operated (skin } \\
\text { closure), survived }\end{array}$ \\
\hline II & F & $22 \mathrm{~W}$ & $21 \mathrm{yrs}$ & $38 \mathrm{~W} / 2100 \mathrm{~g}$. & C.S. & $<5 \mathrm{cms}$ & $\begin{array}{l}\text { Myelomeningocele } \\
\text { Cloacal extrophy }\end{array}$ & $\begin{array}{l}\text { Dead on the } 7 \text { th } \\
\text { day of life }\end{array}$ \\
\hline III & $\mathrm{F}$ & $20 \mathrm{~W}$ & $28 \mathrm{yrs}$ & $34 \mathrm{~W} / 1800 \mathrm{~g}$. & C.S. & $>5 \mathrm{cms}$ & $\begin{array}{l}\text { Extrophic cloaca } \\
\text { Uncorrectable h. defect }\end{array}$ & Stillborn \\
\hline IV & M & $16 \mathrm{~W}$ & $30 \mathrm{yrs}$ & $38 \mathrm{~W} / 1400 \mathrm{~g}$. & C.S. & $>5 \mathrm{cms}$ & $\begin{array}{l}\text { Imperforated anus } \\
\text { Uncorrectable } h \text {. defect }\end{array}$ & Stillborn \\
\hline V & M & $35 \mathrm{~W}$ & $30 \mathrm{yrs}$ & $42 \mathrm{~W} / 3300 \mathrm{~g}$ & Vag. & $<5 \mathrm{cms}$ & $\begin{array}{l}\text { Left P. U. J. obstr. } \\
\text { Tetralogy of Fallot }\end{array}$ & $\begin{array}{l}\text { Operated (one stage } \\
\text { closure), survived }\end{array}$ \\
\hline VI & M & $28 \mathrm{~W}$ & $19 \mathrm{yrs}$ & $40 \mathrm{~W} / 2100 \mathrm{~g}$. & C.S. & $>5 \mathrm{cms}$ & Left diaph. hernia & Dead after treatment \\
\hline VII & M & $31 \mathrm{~W}$ & $26 \mathrm{yrs}$ & $37 \mathrm{~W} / 2800 \mathrm{~g}$. & C.S. & $<5 \mathrm{cms}$ & Cleft lip microcephalic & Stillborn \\
\hline VIII & $\mathrm{F}$ & $33 \mathrm{~W}$ & $36 \mathrm{yrs}$ & $39 \mathrm{~W} / 1840 \mathrm{~g}$. & C.S. & $>5 \mathrm{cms}$ & $\begin{array}{l}\text { Complex hearth defect } \\
\text { Club feet }\end{array}$ & Stillborn \\
\hline IX & $\mathbf{M}$ & $24 \mathrm{~W}$ & $20 \mathrm{yrs}$ & $38 \mathrm{~W} / 3400 \mathrm{~g}$. & C.S. & $>5 \mathrm{cms}$ & - & $\begin{array}{l}\text { Giant omphalocele } \\
\text { (Mercurochrome), } \\
\text { sepsis, dead }\end{array}$ \\
\hline $\mathrm{X}$ & M & $29 \mathrm{~W}$ & $23 \mathrm{yrs}$ & $38 \mathrm{~W} / 2280 \mathrm{~g}$. & Vag. & $>5 \mathrm{cms}$ & - & $\begin{array}{l}\text { Operated (skin } \\
\text { closure), survived }\end{array}$ \\
\hline $\mathrm{XI}$ & M & $32 \mathrm{~W}$ & 22 yrs & $39 \mathrm{~W} / 3100 \mathrm{~g}$. & C.S. & $\begin{array}{l}>5 \mathrm{cms} . \\
\text { (ruptured) }\end{array}$ & Pentalogy of Cantrell & Stillborn \\
\hline XII & M & $36 \mathrm{~W}$ & 32 yrs & $40 \mathrm{~W} / 3100 \mathrm{~g}$. & C.S. & $<5 \mathrm{cms}$ & Tetralogy of Fallot & $\begin{array}{l}\text { Operated (one stage } \\
\text { closure), survived }\end{array}$ \\
\hline \multicolumn{9}{|c|}{ Gastroschisis } \\
\hline XIII & $\mathrm{F}$ & $23 \mathrm{~W}$ & 29 yrs & $32 \mathrm{~W} / 1500 \mathrm{~g}$. & Vag. & $>5 \mathrm{cms}$ & - & $\begin{array}{l}\text { Operated (silastic } \\
\text { closure), dead }\end{array}$ \\
\hline XIV & M & $20 \mathrm{~W}$ & $25 \mathrm{yrs}$ & $34 \mathrm{~W} / 2100 \mathrm{~g}$. & Vag. & $>5 \mathrm{cms}$ & - & $\begin{array}{l}\text { Operated (silastic } \\
\text { closure), survived }\end{array}$ \\
\hline
\end{tabular}

cardiovascular system; a significant incidence of chromosomal anomalies was also observed in group A (7.2\%).

The drop in mortality in the most recent series of omphalocele cases which were not detected in utero (group B 1) is significant (1/11 in group B 1 compared to 10/37 in group A). Nevertheless, the influence of associated severe anomalies as the cause of death appears to be constant.
With the introduction of prenatal diagnosis, a higher number of omphalocele cases with associated severe anomalies was observed (9/12 in group B 2), and despite early diagnosis and planned delivery and management, only 6 out of 12 newborns could be helped by surgery. The overall mortality was extremely high (8/ 12) in this group, and the majority of deaths was secondary to multiple malformations. 
Table II. Abdominal wall defects.

\begin{tabular}{|c|c|c|c|c|c|c|}
\hline & \multicolumn{2}{|c|}{$\begin{array}{l}\text { A } \\
(1967-1979)\end{array}$} & \multicolumn{2}{|c|}{$\begin{array}{l}\text { B1 } \\
\text { (Jan. 1980-Apr. 1985) } \\
\text { (not detected in utero) }\end{array}$} & \multicolumn{2}{|c|}{$\begin{array}{l}\text { B 2 } \\
\text { (Jan. 1980-Apr. 1985) } \\
\text { (detected in utero) }\end{array}$} \\
\hline & Omphal. & Gastros. & Omphal. & Gastros. & Omphal. & Gastros. \\
\hline $\mathrm{N}^{\circ}$ & 37 & 18 & 11 & 5 & 12 & 2 \\
\hline Treated & 36 & 18 & 11 & 5 & 6 & 2 \\
\hline Deaths & 10 & 12 & 1 & - & 8 & 1 \\
\hline \multicolumn{7}{|l|}{ Mode of treatment } \\
\hline - Skin flap & 12 & 8 & 4 & - & 3 & - \\
\hline - Mercurochrome & 5 & - & - & - & 1 & - \\
\hline - One stage clos. & 19 & 4 & 7 & 3 & 2 & - \\
\hline - Silastic pouch & - & 6 & 6 & 2 & - & 2 \\
\hline Ass. anomalies & 20 & 5 & 3 & - & 9 & - \\
\hline Immaturity/low birth weight & 8 & 8 & & 3 & 6 & 2 \\
\hline
\end{tabular}

Table III. Abdominal wall defects: causes of death (\%).

\begin{tabular}{|c|c|c|c|c|c|c|}
\hline & \multicolumn{2}{|c|}{$\begin{array}{l}\text { A } \\
(1967-1979)\end{array}$} & \multicolumn{2}{|c|}{$\begin{array}{l}\text { B 1 } \\
\text { (Jan. 1980-Apr. 1985) } \\
\text { (not detected in utero }\end{array}$} & \multicolumn{2}{|c|}{$\begin{array}{l}\text { B } 2 \\
\text { (Jan. 1980-Apr. 1985) } \\
\text { (detected in utero) }\end{array}$} \\
\hline & Omphal. & Gastros. & Omphal. & Gastros. & Omphal. & Gastros. \\
\hline Severe ass. anomalies & $80 \%$ & - & $100 \%$ & - & $87 \%$ & - \\
\hline Sepsis surgical compl. & $10 \%$ & $66 \%$ & - & - & $13 \%$ & - \\
\hline Immaturity & & & & & & \\
\hline Low birth weight & $10 \%$ & $33 \%$ & - & - & - & $100 \%$ \\
\hline
\end{tabular}

In none of the three groups did the mode of treatment appear to influence outcome. Between 1980 and 1985 only one case of post operative sepsis was observed in a prenatally diagnosed giant omphalocele, and this was amenable to Mercurochrome therapy only. When the gastroschisis cases, which did not have a prenatal diagnosis, were examined (groups A and B 1) a dramatic drop in mortality rate was observed among the most recent cases ( $0 / 5$ vs $12 / 18)$. Immaturity/low birth weight rate was constantly high in both groups. Associated abnormalities, when present, were not severe and were compatible with survival. Mortality in group A was mainly associated with surgical complications, immaturity and low birth weight. The mode of treatment (6 prosthetic closures, 8 skin flap closures and 4 one stage closures) did not appear to significantly influence outcome in group A. The two cases of gastroschisis detected before birth were low birth weight babies without associated anomalies. One of them died in the early postoperative period due to respiratory problems related to immaturity. The other survived after a staged closure with the use of a silastic pouch.

A cesarean section rate of $18 \%$ was found in obstetrical histories of patients with abdominal wall defects not detected in utero. Intrapartum rupture of omphalocelic membranes was not indicated. 
Among prenatally discovered cases of abdominal wall defect an induced high rate of cesarean sections was reported $(70 \%)$. Only one ruptured omphalocele was observed (case XI). It was detected in utero at 32 weeks and could not be followed up. The mother was admitted in advanced labor with ruptured membranes at 39 weeks, and a stillborn male infant with pentalogy of Cantrell was operatively delivered.

\section{Discussion}

With an omphalocele the most important factors affecting survival are associated anomalies (mainly cardiovascular), chromosomal defects and low birth weight. In gastroschisis mortality is usually secondary to surgical complications [9]. While the omphalocele sac protects intestinal loops from amniotic fluid and postnatal injuries, in gastroschisis the herniated viscera appear edematous and thickened. This aspect is usually worse in late referred cases. Postoperative sepsis and prolonged ileus are described as the two main problems with treatment of this anomaly.

The optimal method for operative management of an abdominal wall defect remains controversial, and wide variations of opinions and enthusiasm for different procedures have been presented in the literature in the past 30 years [2-4]. When a one stage closure is made impossible by the risk of ventilatory and caval circulation compromise, skin flap closure or, in the past, escharification of the sac with Mercurochrome were the only alternatives. The prosthetic sac closure, especially in large gastroschisis, was a milestone achievement and contributed to reduce mortality of these patients [10]. Nevertheless, all these staged procedures carry some risk and need multiple operations.

Recently, intraoperative abdominal wall stretching, gentle evacuation of gastrointestinal content and postoperative paralysis and mechanical ventilation for some days have been proposed to achieve primary closure even in large defects [1].
The improvement in treatment of abdominal wall defects also reflects the advances that have been made in general neonatal care, anesthetic techniques and availability of new supportive measures. This is reflected in a larger survival rate for babies with gastroschisis [6] as was confirmed by our data.

Early treatment soon after delivery of this anomaly, permitted by prenatal diagnosis, may reduce exposure and handling of neonatal loops and minimize risks of infection and long postoperative ileus.

Despite current methods of treatment, mortality due to severe associated malformations [7] has not been significantly changed among infants with omphalocele. With prenatal diagnosis a larger number of these newborns are now seen in the early perinatal period. Among them there are many cases that, without antenatal detection and maternal transport, would never have been living long enough to be observed by the surgeon. This may explain the paradoxally high mortality rate (overall and surgical) in prenatally diagnosed cases. Careful antenatal search for associated anomalies is mandatory for a better prognostic evaluation of omphalocele cases. Concerns about potential dystocia with large omphaloceles and about injury and contamination of the abdominal content in gastroschisis have increased the use of cesarean section in our cases. There is no evidence of a real benefit from cesarean section. No intrapartum rupture of an omphalocele sac has been reported in all our cases abserved prior to the introduction of prenatal diagnosis. The presence of associated anomalies and unavoidable poor outcome in many of these fetuses must be considered before increasing maternal risk with an operative delivery.

\section{Conclusion}

Benefit of earlier treatment is not demonstrable from our small number of cases of gastroschisis detected in utero and treated immediately following birth. 
In the omphalocele cases, associated anomalies have been an unavoidable limiting factor in improving the overall and surgical mortality rates. We must also consider that with prenatal diagnosis a large number of cases destined, in the past, to be stillborn or to die before referral to a surgical center are now observed and sometimes treated by pediatric surgeons.

Potentially better outcomes for fetuses with abdominal wall defects may be expected with the introduction of prenatal diagnosis. Reduction of risks related to perinatal transport and a better quality of surgery and supportive measures in a well equiped center may lead to a higher survival rate when multiple complex deformities incompatible with life are not present. These cases must be identified before birth.

The question of whether cesarean section should be the preferred method of delivery is still being debated [8]. In our opinion, extensive indication for operative delivery does not appear to be sufficently justified.

\section{Summary}

Despite prenatal diagnosis, maternal transport and early perinatal treatment in specialized hospitals, improvement in overall mortality has not been observed among newborns with abdominal wall defects (omphalocele and gastroschisis). A comparison has been made, for both anomalies, between 55 cases treated in the periods $1967-1979$ and 30 treated in the periods $1980-1985$. In this last group, 14 prenatally detected cases were separated from cases discovered at birth. Recent advances in treatment have reduced mortality rates for both of these anomalies. This was especially true for gastroschisis; in omphalocele cases, associated abnormalities appeared to be an unavoidable limiting factor in survival. With prenatal diagnosis a surprising increase in mortality rate was observed among omphalocele cases detected before birth. A possible reason for this is the total number of antenatally diagnosed cases that, with maternal transport, are concentrated in centers where surgical facilities are available. Before introduction of antenatal diagnosis, most of these cases would never

have been observed by the pediatric surgeon because of death prior to referral or treatment.

Gastroschisis cases may benefit more from antenatal recognition and early treatment because multiple abnormalities or immaturity are not so important limiting factors in survival as in omphalocele cases. Reduced trauma and contamination of exposed viscera, immediate treatment and adequate supportive measures may significantly reduce mortality rate in gastroschisis cases. Operative delivery of fetuses with an abdominal wall defect is controversial. The risk of vaginal route delivery has been over emphasized. Intrapartum rupture of an omphalocelic sac was an extremely rare event before introduction of antenatal diagnosis. It is the authors' opinion that extensive indication for cesarean section is not justified because it increases maternal risk and has an uncertain benefit for the fetus. In conclusion, antenatal diagnosis may potentially contribute to improve results in treatment of abdominal wall defects, provided that multiple, untreatable malformations are not present.

Keywords: Gastroschisis, omphalocele, prenatal diagnosis.

\section{Zusammenfassung}

\section{Geburtsleitung und klinischer Zustand bei Neugeborenen mit Bauchwanddefekten}

Trotz pränatal gestellter Diagnose, Einweisung der Mütter in Spezialkliniken und früher perinataler Behandlung dort konnte keine Senkung der Gesamtmortalität Neugeborener mit Bauchwanddefekten (Omphalocele und Gastroschisis) beobachtet werden. Es wurden für beide Anomalien 55 Fälle, die in den Jahren 1967-1979 behandelt worden waren, mit 30 Fällen aus den Jahren 1980-1985 verglichen. In der letzteren Gruppe wurden 14 pränatal diagnostizierte Fälle von den restlichen, die erst bei der Geburt festgestellt wurden, getrennt betrachtet.

Durch die jüngsten Fortschritte in der Behandlung konnte die Mortalitätsrate für beide Anomalien erheblich gesenkt werden. Dies trifft insbesondere auf die
Gastroschisis zu; bei Fällen von Omphalocele scheinen damit assoziierte Anomalien ein limitierender Faktor für das Überleben zu sein, der nicht überwunden werden kann. Mit zunehmender Verbreitung der Pränataldiagnostik wurde ein überraschender Anstieg der Mortalität bei Fällen von pränatal festgestellter Omphalocele beobachtet. Ein möglicher Grund hierfür ist die Gesamtzahl pränatal diagnostizierter Fälle, die durch Einweisung der Mutter in Zentren konzentriert werden, die über die nötigen chirurgischen Einrichtungen verfügen. Vor Einführung der Pränataldiagnostik wurde der Großteil dieser Fälle niemals von einem Kinderchirurgen beobachtet, da die Neugeborenen bereits vor der Einweisung zur Therapie verstarben.

Neugeborene mit Gastroschisis mögen stärker von der pränatalen Diagnostik und früh einsetzenden Behand- 
lung profitieren, da multiple Anomalien oder Unreife als limitierende Faktoren nicht so ins Gewicht fallen wie bei Fällen mit Omphalocele.

Reduzierte Traumatisierung und Kontamination der exponierten Organe, sofortige Therapie und angemessene unterstützende Maßnahmen können die Mortalitätsrate bei Gastroschisis signifikant herabsetzen. Die operative Entbindung von Feten mit Bauchwanddefekt wird kontrovers beurteilt. Das Risiko einer vaginalen Geburt wurde überbetont. Die Ruptur eines Omphalocelensacks war auch vor Einführung der Pränataldiagnostik ein extrem seltenes Ereignis. Nach Meinung des Autors ist die weit gestellte Indikation für einen Kaiserschnitt nicht gerechtfertigt, weil das mütterliche Risiko erhöht wird zugunsten eines ungewissen Vorteils für den Feten. Abschließend kann gesagt werden, daß pränatale Diagnostik möglicherweise dazu beitragen kann, die Ergebnisse bei der Behandlung von Bauchwanddefekten zu verbessern, vorausgesetzt, daß keine multiplen unbehandelbaren Mißbildungen vorliegen.

Schlüsselwörter: Gastroschisis, Omphalocele, pränatale Diagnostik.

\section{Résumé}

Anomalies de la paroi abdominale chez le fatus prise encharge et devenir

Malgré le diagnostique prénatal, le transport maternel et le traitement précoce périnatal en hopitaux spécialisés, on n'a pas assisté à une diminution du taux de mortalité chez les nouveaux-nés présentant des défauts de la paroi abdominale (omphalocèle et gastroschisis). Une comparaison a été faite, pour les deux anomalies, entre les 55 cas traités pendant la période de 1967 à 1979 et les 30 cas traités pendant la période de 1980 à 1985. Dans ce dernier groupe, 14 cas ont été découverts à la naissance. Les récents progrès dans le traitement ont réduit le taux de mortalité pour les deux anomalies. Cela est particulièrement vrai pour les gastroschisis, tandis que parmis les cas d'omphalocèle, les anomalies associées semblent être un facteur inévitable limitant la survie. Une surprenante augmentation du taux de mortalité a été observée parmis les cas d'omphalocèle découverts avant la naissance. Une possible explication de ce phénomène est fournie par le fait que la quasi totalité des cas diagnostiqués avant la naissance, est concentrée dans les centres spécialisés, grâce au transport maternel. Avant l'introduction du diagnostique prénatal la plus part de ces cas était rarement observés par le chirurgien à cause de la mort du patient avant le transport ou le traitement. Les cas de gastroschisis ont bénéficié d'avantage de la découverte prénatale et du traitement précoce car les anomalies multiples ou l'immaturité ne sont pas des facteurs limitants la survie aussi importants que les malformations associées à l'omphalocèle. La réduction du traumatisme et de la contamination des viscères exposés, le traitement immédiat et les soins intensifs peuvent reduire considérablement le taux de mortalité pour les cas de gastrischisis.

La césarienne pour les fœtus ayant un défaut de la paroi abdominale est discutée. Le risque de la voie vaginale a été surestimé: en fait la rupture d'un sac omphalocélique pendant l'accouchement était un événement extrèmement rare avant l'introduction du diagnostique prénatal. L'opinion des auteurs est qu'une indication extensive de la césarienne n'est pas justifiée du fait qu'elle augmente les risques maternels et ne donne que des avantages très douteux au fotus. En conclusion, le diagnostique prénatal peut améliorer les résultats du traitement des défauts de la paroi abdominale pourvu que des malformations multiples et intraitables ne soient pas présentes.

Mots-clés: Diagnostique prénatal, gastroschisis, omphalocèle.

\section{References}

[1] Bower RT, MJ Bell, JR Tenberg, ML CoB: Ventilatory support and primary closure of gastroschisis. Surgery 91 (1982) 52

[2] Canty TG, D Collins: Primary fascial closure in infants with gastroschisis and omphalocele: a superior approach. J Pediatr Surg 18 (1983) 707

[3] DE VRIES P: The pathogenesis of gastroschisis and omphalocele. J Pediatr Surg 15 (1980) 245

[4] EỊN SH, ZR RUBIN: Gastroschisis: primary closure or silon pouch. J Pediatr Surg 15 (1980) 549

[5] HaRrison MR, MS Golbus, RA Filly: The unborn patient. Prenatal diagnosis and treatment. Grune and Stratton, Orlando, FL-London 1984

[6] Hofmann V, S Kap Herr, P Emmrich: Causes of postoperative deaths in gastroschisis and omphalocele. Prog Pediatr Surg 13 (1979) 63
[7] Hollabought RS: The management of gastroschisis. J Pediatr Surg 8 (1973) 263

[8] KIRK P, R WAH: Obstetric management of the fetus with omphalocele or gastroschisis: a rewiew and report of one hundred twelwe cases. Am J Obstet Gynecol 146 (1983) 512

[9] Mayer T, R Black, ME matlak, T Mayer, $R$ BLACK, ME MatLaK, DG Johnson: Gastroschisis and omphalocele. Ann Surg 192 (1980) 783

[10] Schwartz M, K Tyson, K Milliorn, T LobE: Staged reduction using a silastic sac in the treatment of choice for large congenital abdominal wall defects. J Pediatr Surg 18 (1983) 713

Received November 9, 1985. Accepted March 21, 1986.

Prof. Luigi Perrelli Via Bruxelles, 67 00198 Rome, Italy 